\title{
Transfusion practices in the pediatric and neonatology departments of Soavinandriana hospital center
}

\author{
Lalao Tsifiregna R. ${ }^{1 *}$, Rakotomahefa Narison M. $^{2}$, Nambininjanahary F. ${ }^{3}$, Lalaina Robinson A. ${ }^{4}$ \\ Rakoto Alison $0^{5}$
}

DOI: https://doi.org/10.17511/ijpr.2020.i05.04

\begin{abstract}
1* Rosa Lalao Tsifiregna, Department of Pediatrics and Neonatology, Hospital Center of Soavinandriana, Antananarivo, Madagascar. ${ }^{2}$ Mbola Rakotomahefa Narison, Pediatric Oncology Pilot Unit, Joseph Ravoahangy Andrianavalona Hospital Center, Antananarivo, Madagascar. ${ }^{3}$ Filaminantsoa Nambininjanahary, Department of Pediatrics and Neonatology, Hospital Center of Soavinandriana, Antananarivo, Madagascar. ${ }^{4}$ Annick Lalaina Robinson, Child Mother Hospital, Anatananarivo, Madagascar. ${ }^{5}$ Olivat Rakoto Alison, Hematology Unit, Joseph Ravoahangy Andrianavalona Hospital Center, Antananarivo, Madagascar.
\end{abstract}

Blood transfusion is an important part of day-to-day clinical practice. The main objective of this work is to describe transfusion practices in the Pediatrics and Neonatology Department of the Hospital Center of Soavinandriana. Methods: A prospective observational study of 6 months has been conducted. All requests to Department of Pediatrics and Neonatology for blood for transfusion for children aged less than 14 years were identified prospectively. The variables studied were: patients' characteristics (age, gender) reason for hospitalization, paraclinical examinations (blood count and formula before transfusion, $A B O$ and Rhesus grouping), the presented pathology, the indicated transfusion: nature, incidents during and after transfusion and the outcome of the pathology (healing, death). Results: The incidence was $6.54 \%, 33$ patients had a blood transfusion. The sex ratio was 1.35 . The average age is 46.06 months. Skin pallor was the main reason for hospitalization, which represented $18.18 \%$ of the cases. The average hemoglobin level was 8.08 $\mathrm{g} / \mathrm{dl}$. The $\mathrm{O}$ and rhesus positive blood group was the predominant in this work. The blood products which were used were: red blood cell $(n=20,54.05 \%)$, whole blood $(n=15,40.54 \%)$, fresh frozen plasma $(n=1,2.70 \%)$, platelets concentrate $(n=1,2.70 \%)$. Conclusion: The packed red blood cell was used the most and the hospital blood bank did not have enough labile blood products. It is therefore essential to improve the structures for the preparation of blood and its derivatives, in order to make all varieties of labile blood products accessible.

Keywords: Blood transfusion, Practices, Antananarivo

Corresponding Author

Rosa Lalao Tsifiregna, Department of Pediatrics and Neonatology, Hospital Center of Soavinandriana, Antananarivo, Madagascar. Email: rosalalao@yahoo.fr

$\begin{array}{cc}\begin{array}{c}\text { Manuscript Received } \\ 2020-03-27\end{array} & \begin{array}{c}\text { Review Round } \mathbf{1} \\ 2020-04-05\end{array} \\ \text { Conflict of Interest } & \text { Funding } \\ \text { No } & \text { Nil }\end{array}$

(C) 2020 by Rosa Lalao Tsifiregna, Mbola Rakotomahefa Narison, Filaminantsoa Nambininjanahary, Annick Lalaina Robinson, Olivat Rakoto Alison and Published by Siddharth Health Research and Social Welfare Society. This is an Open Access article licensed under a Creative Commons Attribution 4.0 International License https://creativecommons.org/licenses/by/4.0/
unported [CC BY 4.0].
How to Cite this Article

To Browse

Tsifiregna AL, Narison MR, Nambininjanahary $F$, Robinson AL, Alison OR. Transfusion practices in the pediatric and neonatology departments of Soavinandriana hospital center. Pediatric Rev Int J Pediatr Res. 2020;7(5):210-216.

Available From

https://pediatrics.medresearch.in/index.php/ijpr/arti cle/view/582

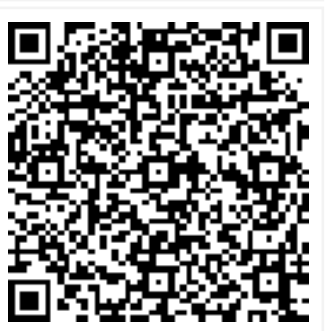




\section{Introduction}

Blood transfusion is a complementary therapy, which consists of compensating for the loss or insufficiency of blood or one of its components [1]. It is an important part of day-to-day clinical practice. In pediatrics, blood transfusion is based on a set of procedures which guarantee blood products that are adapted to the child's needs, without harming his development or his bloodimmunological status.

In France, six percent of transfused labile blood products are delivered for pediatrics [2]. The transfusion rate was $85.7 \%$ in Cameroon and $70 \%$ in Kenya [3]. In 2013, a study carried out at the University Hospital Center of Fianarantsoa objectified that $10.4 \%$ of the transfused patients were from 0 to 10 years old [4]. In the Pediatrics department of Joseph RasetaBefelatanana Hospital, eighty-two percent of sickle cell patients hospitalized during the period studied had received a blood transfusion [5].

Very few qualitative and quantitative data on transfusion needs are available or even non-existent in the Pediatrics and Neonatology Department of the Hospital Center of Soavinandriana (CENHOSOA).

This observational study was performed to describe transfusion practices in the aforementioned departments. The knowledge of these data would make it possible to estimate the annual labile blood product needs of the CENHOSOA Pediatrics department, in order to contribute to the management of the hospital's blood bank stocks.

\section{Methods}

The study was conducted at the Department of Pediatrics and Neonatology of the Hospital Center of Soavinandriana (CENHOSOA) located in Antananarivo, the capital of Madagascar. The department has a pediatric resuscitation unit, a neonatal resuscitation unit, a conventional hospitalization unit, having 54 beds in total. Children having undergone a surgical intervention carried out by the pediatric surgery and neurosurgery team are also taken care over there. CENHOSOA has a blood bank service inside the compound, which has been functional since ten years. A prospective observational study design, from April 1st, 2016 until October 31st, 2016 has been conducted.
All requests to Department of Pediatrics and Neonatology for blood for transfusion for children aged less than 14 years. It was an exhaustive sampling. We excluded patients who had a blood transfusion during surgery in the operating room.

The variables studied were: patients' characteristics (age, gender) reason for hospitalization, paraclinical examinations (blood count and formula before transfusion, $A B O$ and Rhesus grouping), the presented pathology, the indicated transfusion: nature, incidents during and after transfusion and the outcome of the pathology (healing, death). Data extraction was undertaken by the clinicians. The data were entered onto EXCEL and exported to statistical software (EPI INFO 7) for analysis. Frequencies and percentages were calculated to describe findings

Permission to collect the data was also obtained from parents. The data were processed anonymously.

\section{Results}

There were 504 pediatric admissions to the service and 33 pediatric blood transfusion requests, an incidence of $6.54 \%$. The sex ratio was 1.35 . The average age is 46.06 months, i.e. 3 years and 9.96 months old, with extremes of DO and 13 years old. (Table I).

\section{Table-I: Age distribution}

\begin{tabular}{|l|l|l|}
\hline \multicolumn{1}{|c|}{ Age (months) } & Number $(\mathrm{n}=\mathbf{3 3})$ & \multicolumn{1}{c|}{ Proportion (\%) } \\
\hline$<1$ & 9 & 27,27 \\
\hline $1-6$ & 3 & 9,09 \\
\hline $6-12$ & 8 & 24,24 \\
\hline $12-24$ & 2 & 6,06 \\
\hline $24-60$ & 2 & 6,06 \\
\hline $60-120$ & 3 & 9,09 \\
\hline $120-180$ & 6 & 18,18 \\
\hline
\end{tabular}

Table II shows the reasons for admission.

In the history, we found 4 sickle cell anemia, 6 prematurity, and 3 intrauterine growth restriction (IUGR). A patient had a previous transfusion and 2 newborns were born in a background of hemorrhagic placenta previa. Infectious and hematological pathologies were the most encountered in these transfused patients. (Table III). 
A hemogram was prescribed for all 33 patients in our series, 1 of whom did not obtain his result (Table IV). The average $\mathrm{Hb}$ was $8.08 \mathrm{~g} / \mathrm{dl}$ with extreme values of $2.4 \mathrm{~g} / \mathrm{dl}$ and $16 \mathrm{~g} / \mathrm{dl}$.

Table-II: Reasons for admission.

\begin{tabular}{|l|l|l|}
\hline \multicolumn{1}{|c|}{ Reasons for admission } & Number $(\mathbf{n}=\mathbf{3 3})$ & Proportion (\%) \\
\hline Fever & 5 & 15,15 \\
\hline Skin pallor & 6 & 18,18 \\
\hline Shortness of breath & 4 & 12,12 \\
\hline Hemorrhagic syndrome & 4 & 12,12 \\
\hline Pain syndrome & 3 & 9,09 \\
\hline Prematurity & 2 & 6,06 \\
\hline Others & \multicolumn{2}{|l|}{} \\
\hline Soft tissue swelling & 2 & 6,06 \\
\hline Vomiting & 1 & 3,03 \\
\hline Trauma & 1 & 3,03 \\
\hline Edematous syndrome & 1 & 3,03 \\
\hline Epigastralgia & 1 & 3,03 \\
\hline Cranial malformation & 2 & 6,06 \\
\hline Refusal to feed & 1 & 3,03 \\
\hline
\end{tabular}

Table III: Pathology.

\begin{tabular}{|l|l|l|}
\hline \multicolumn{1}{|c|}{ Pathology } & Number $(\mathbf{n = 3 3 )}$ & Proportion $(\%)$ \\
\hline Infectious pathology & 15 & 45,45 \\
\hline Hematologic pathology & 12 & 36,36 \\
\hline Surgery pathology & 4 & 12,12 \\
\hline Others & \multicolumn{2}{|l|}{} \\
\hline Road accident & 1 & 3,03 \\
\hline Rheumatic heart & 1 & 3,03 \\
\hline
\end{tabular}

Table IV: Blood count.

\begin{tabular}{|l|l|l|}
\hline \multicolumn{2}{|l|}{ Number } & \multicolumn{1}{|l|}{ Proportion (\%) } \\
\hline Hemoglobin level & \multicolumn{1}{|l|}{} \\
\hline New born & 1 & 11,11 \\
\hline $\mathrm{Hb}<10 \mathrm{~g} / \mathrm{dl}$ & 8 & 88,89 \\
\hline $\mathrm{Hb}>10 \mathrm{~g} / \mathrm{dl}$ & \multicolumn{3}{|l|}{} \\
\hline Infants and children & 9 & 39,13 \\
\hline $\mathrm{Hb}<7 \mathrm{~g} / \mathrm{dl}$ & 10 & 43,47 \\
\hline $7 \leq \mathrm{Hb}<10 \mathrm{~g} / \mathrm{dl}$ & 4 & 17,40 \\
\hline $\mathrm{Hb} \geq 10 \mathrm{~g} / \mathrm{dl}$ & 15 & 46,88 \\
\hline Platelets & 17 & 53,12 \\
\hline$<150$ 000/mm3 & 4 \\
\hline$>150$ 000/mm3 & 14 & 43,53 \\
\hline Mean Corpuscular Volum (MCV) & 15,62 \\
\hline$<70 \mathrm{fl}$ & 5 & 42,85 \\
\hline$>100 \mathrm{fl}$ & 15 & 34,38 \\
\hline $70 \mathrm{fl}-100 \mathrm{fl}$ & 12 & 65,62 \\
\hline Mean Corpuscular Hemoglobin Concentration (MCHC) \\
\hline$<32 \%$ & 20 & \\
\hline$>32 \%$ &
\end{tabular}

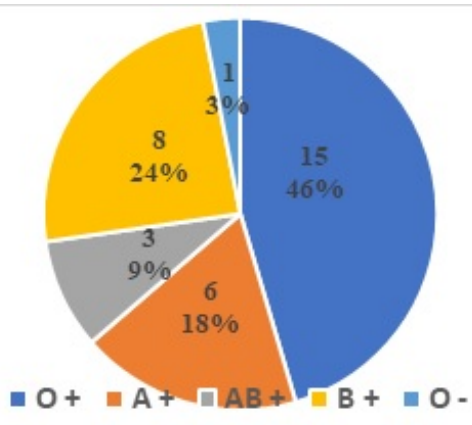

Figure-1: Distribution by blood type

Figure 1 describes the distribution of patients by blood group.

The blood products which were used were: red blood cell $(n=20,54.05 \%)$, whole blood $(n=15$, $40.54 \%)$, fresh frozen plasma $(n=1,2.70 \%)$, platelets concentrate $(n=1,2.70 \%)$. A patient could not receive his transfusion due to the lack of stock in the blood bank while a triple transfusion was carried out for a patient, made of packed red blood cells, whole blood, and fresh frozen plasma.

The National Center for Blood Transfusion of the Joseph Andrianavalona University Hospital Center had delivered the vast majority of the used blood bags. No incident was reported during the blood transfusion. Seven deaths were encountered during our study, ie a mortality rate of $21.21 \%$, one of which had no transfusion due to the unavailability of a blood bag.

\section{Discussion}

Transfusion occupies a great considerable place in pediatric environment; it is an act that should not be neglected for young children. In our study, 33 patients received a blood transfusion, i.e. an incidence of $6.54 \%$. Rakotoaritiana found a proportion of $10.4 \%$ of children who are less than 10 years old, who received a blood transfusion in his work carried out at University Hospital Center of Fianarantsoa, Madagascar [4]. A study conducted at the "Coast Provincial General Hospital » in Kenya showed a hospital incidence of $15.88 \%$, during two years study period [6]. In Zimbabwe, over a 12month period, in the four major national hospitals, a transfusion rate of $13.4 \%$ for those who are less than 15 years old was objectified [7].

The average age in our study was 46.06 months old, i.e. 3 years and 9.96 months old with an extremity from D0 to 13 years old; 
While in the county hospital in Kenya, on the same study, this average was 33.6 months or 2 years and 9.6 months old [8]. In general, patients who are less than 2 years old were at risk groups and the most numerous to be transfused in our study $(66.664 \%)$. This was confirmed by CheloDwith a value of $55.30 \%$ in children under two years old [9]. But $V$. Dan found a more advanced age. According to his research, $84 \%$ of the transfused children in the department were under 3 years old with a peak between birth and 12 months old [10]. Several literatures noted that the age below 5 years old was the most transfused, like Okoko. A.R. and al in Brazzaville [11]. Regarding the age groups, the newborns were those who needed transfusion the most, with a percentage of $27.7 \%$. This result is explained by the fact that these patients who are admitted to the neonatology units constitute a group of individuals particularly exposed to the risk of transfusion, because of their physiological and pathological characteristics [12]. In the study of AsmaAdny about 169 neonatal anemia cases, collected in the neonatology department of the $\mathrm{CHU}$ Mohamed VI of Marrakech during a period of 2 years, 20 cases of newborns were transfused, i.e. a percentage of $11.83 \%$ [1].

Skin pallor was the main reason for admission, which represented $18.18 \%$ of the cases in our study, followed by fever in $15.15 \%$ of cases $(n=5)$, hemorrhagic syndrome $(12.12 \%)$ and shortness of breath $(12.12 \%)$. According to a study in Cameroon in two pediatric departments in Yaoundé in 2016, the first reason for consultation among children was the pale color of the teguments, observed in 161 patients $(40.86 \%)$, followed by fever in 127 patients $(32,20 \%)$ and intense asthenia in 90 patients $(22.84 \%)$ [9]. There are a variety of reasons according to the studies, through the analysis, but skin-mucous pallor and fever are the main reasons for admission, followed by shortness of breath. Moreover, fever, diarrhea and acute respiratory infections were the most significant health problems in children [13]. A study carried out in Yaoundé by Djeutchouang made it possible to report a high frequency $(74.3 \%)$ of fever in anemic patients [14]. According to KedyKoumDand al, skin and mucous pallor, asthenia, tachycardia and dyspnea were the main signs found in anemic patients [15].

The average hemoglobin level was $8.08 \mathrm{~g} / \mathrm{dl}$ with extreme values of $2.4 \mathrm{~g} / \mathrm{dl}$ and $16 \mathrm{~g} / \mathrm{dl}$. This result is close to what has been published in Cameroon with an average hemoglobin level of $8.6 \pm 1.7 \mathrm{~g} / \mathrm{d}$ [15].
In the pediatric resuscitation department in Montreal, Gauvin founda pre-transfusion hemoglobin rate of $8, \mathrm{lg} / \mathrm{dl}$ with extreme values of 3.8 and $17, \mathrm{lg} / \mathrm{dl}$ [16]. On the other hand, the average hemoglobin level found in our study was a little bit high compared to that which Pascal Korgo found in Burkina Faso, a rate of $4.08 \mathrm{~g} / \mathrm{dl}$ [1].The indication for a blood transfusion takes into account the values of the erythrocyte constants and above all the clinical tolerance.

The $O$ and rhesus positive blood group was the predominant in this work. In a study carried out by Rakotosalamain 2005 at the Emergency and Intensive Care Unit CHU Mahajanga Androva, the "O" groups occupy the first place among the transfused patients, 17out of 34 patients in total, one of whom represents a Rhesus negative [17]. According to Rahanitrarisoa on the evaluation of transfusion practice in the surgical intensive care unit at $\mathrm{CHU}$ Ampefiloha, people in the $\mathrm{O}+$ group are the most important among transfused patients in this department, i.e. $40.56 \%$, followed by $B+$ group who represent $31,13 \%$ and $A+, A B+$ and finally $O-$ [18]. The predominance of the O+ blood group was also found in Mahajanga and Fianarantsoa with a proportion of $45 \%$ and $41.8 \%$ respectively. These results seem to suppose that the $\mathrm{O}+$ blood group constitutes the predominant group in Madagascar. But as the blood group profile of malagasy is not yet well established and clarified, we only stayed with this observation.

Blood cell transfusion was by far the most widely prescribed in $54.05 \%$ of the transfusion cases. According to a study carried out at the $\mathrm{CHU}$ Brazzaville on pediatric transfusion activity, the most used blood product is the globular concentrate $(98.3 \%)$, then the whole blood $(1.4 \%)$, and finally the fresh frozen plasma $(0,3 \%)$ [9]. Unlike the result of David Chelo, which shows that whole blood was the most transfused in 338 children $(84.5 \%)$ while $62(15.5 \%)$ received red blood cells [11].

Fifteen patients received a whole blood transfusion, $42.86 \%$ of the cases. For other authors, the whole blood was the main blood product delivered: $84.50 \%$ for Libite $P[19]$. Garbaand Ouethy respectively observed that $89.31 \%$ and $100 \%$ of the label blood products used were whole blood $[20,21]$. The absence or scarcity of the production of other blood product types in these developing countries can be due to the lackof material or the absence of appropriate technical capacity for the preparation and treatment of the donors' blood. 
Mr. Chobli wrote that Africa, in particular, benefits little (and sometimes not even at all) from the technological and organizational progress in blood transfusion [22]. As a result, many children received whole blood instead of the prescribed and indicated blood cell.

The National Center for Blood Transfusion of the Joseph Andrianavalona University Hospital Center had delivered the vast majority of the blood bags which are used (91.90\%). During this study, we could see that our blood bank did not have a qualification and transformation of the blood products. We only havepacked red blood cell and whole blood in our blood bank. The production of blood derivatives at CENHOSOA remains embryonic. Under-equipment and lack of reagents are the main problems for the production and availability of blood products. This handicap of by-products deprives the prescriber of the choice of the product adapted to transfusion pathology.

Our study was limited to patients admitted to the CENHOSOA Pediatrics and Neonatology Department, therefore cannot represent all pediatric patients in the country. However, our results may serve as a reference for future studies and may provide an estimate of the use of labile blood products in the pediatric and neonatal department of CENHOSOA.

\section{Conclusion}

This study allowed us to better visualize the use of blood transfusion within the pediatric department of the Hospital Center of Soavinandriana. An incidence of $6.54 \%$ has been objectified. The $O$ rhesus positive blood group was predominant. The packed red blood cell was used the most and the hospital blood bank did not have enough labile blood products. It is therefore essential to improve the structures for the preparation of blood and its derivatives, in order to make all varieties of labile blood products accessible.

\section{Author Contribution}

- Conception and design of the work : Rosa Lalao

- TSIFIREGNA, Filaminantsoa NAMBININJANAHARY

- Data collection Filaminantsoa NAMBININJANAHARY

- Data analysis and interpretation : Mbola RAKOTOMAHEFA NARISON

- Drafting the article; Rosa Lalao TSIFIREGNA
- Critical revision of the article: Annick Lalaina ROBINSON, Olivat RAKOTO ALISON

- Final approval of the version to be published : AnnickLalaina ROBINSON, Olivat RAKOTO ALISON

\section{Reference}

01. MayukuFukiau G, MbayoKalumbu F, Situakiban za Nani Tuma H. Evaluation of the effectiveness of blood transfusion in children in Kinshasaexperience of three medical trainings. Transfusion Clinique et Biologique. 2013;20;

361. DOI: 10.1016/j.tracli.2013.03.248 [Crossref]

02. Navarro C, Ducher E, Tas H, Chabre C, F Deméocq, $\mathrm{P}$ Fabrigli et al. Transfusion practices in pediatrics- retrospective monocentric study. Arch Ped. 2011 Nov;18;1154-61.

DOI: $\quad 10.1016 /$ j.arcped.2011.08.010 [Crossref]

03. Nguefack1 F, Chelo1 D, Tejiokem MC, Pondy A, Njiki kinkela1 MJ, Dongmo R and al. Frequency of severe anemia in children aged 2 months to 15 years at Mother and Child Centre of the Chantal Biya Foundation Yaounde, Cameroon. Pan Afr Med J. 2012;12;46.

Available online at: [Article] [Crossref]

04. Rakotoaritiana RU. Prescription of blood transfusion at the Fianarantsoa University Hospital [Thesis]. Human medicineAntananarivo. 2013n 8501;45p.

Available at: [Article] [Crossref]

05. Rakotovao AF. Epidemio-clinical study of sickle cell anemia in the pediatric service HJRB [Thesis]. Human medicine- Antananarivo. 2012; n 8352;60p.

Available at: [Article] [Crossref]

06. Nabwera HM, Greg F, Jay S, Douglas D, Kishor M. Pediatric blood transfusion practices at a regional referral hospital in Kenya. Transfusion. 2016 Nov;56(11)2732-2738. DOI: $10.1111 /$ trf.13774 [Crossref]

07. Nyashadzaishe M, Star K, Oliver H, Brian E, Isaac $K$, David $A$ et al. Profiles of blood and blood component transfusion recipients in Zimbabwe. Blood Transf. 2015;13;600-9. DOI: 10.2450/2015.0019-15 [Crossref] 
08. Julius T, Philip A, Morris O, Susan G, Boniface M, Wycliffe $\mathrm{N}$ et al. Blood Transfusion Delay and Outcome in County Hospitals in Kenya. Am Soc Too Med Hyg. 2017;96(2)511-7.

DOI: 10.4269/ajtmh.16-0735 [Crossref]

09. Chelo D, Monebenimp F, Francisse $X$, Oouogue T, Abena Obama MT. Determinants of mortality of children under-5 years transfused in two pediatric services of Yaounde. Cameroon Health Sci. 2016 March;17(1).

Available at: [Article] [Crossref]

10. Dan V, Koumakpai S, Hazoume F, Latoundji S, Ayivi B. Transfusion problems in the pediatrics and medical genetics department of the national hospital and university center of Cotonou. Med Afr Noire. 1992;3(7).

Available online at: [Article] [Crossref]

11. Okoko AR, Galiba FO, Oko A, Moyen-Engoba, Moyen G. Pediatric transfusion activity at Brazzaville University Hospital Centre. Rev CAMES. $2008 ; 6 ; 30-3$.

[Crossref]

12. Arnaud F, Simeoni U. Blood Product Transfusion in the Neonatal Period. Transfus Clin Biol. 2005 Oct; $12(4) 336-41$.

DOI: $\quad 10.1016 / j . t r a c l i .2005 .07 .003 \quad$ [Crossref]

13. Roger $P$, Kelodjoue S, Dzossa D, Fomo M, Niekou $\mathrm{R}$, Jazet $\mathrm{E}$ et al. Demographic and Health Survey and with Multiple Indicators, National Institute of Statistics (INS), Ministry of Planning, Programming, Development and Spatial Planning, Ministry of Public Health, Yaoundé, Cameroon. Calverton, Maryland, USA- INS and ICF International. 2012 Sept.

[Crossref]

14. Djeutchouang Sayang C. Interest of the use of rapid diagnostic tests for malaria on the cost and effectiveness of the management of febrile patients in Yaoundé, Cameroon [Thesis]. Human medicine- Marseille, France. 2010;98p.

Available at: [Article] [Crossref]
15. KedyKoum D, Ngouadjeu Dongho Tsakeu E, Ngo Sack F, Tchienrg P, Ngalagou M et al. Clinical and Biological Aspects of Pediatric Anemia in a Urban District Hospital in Cameroon. Pan Afr Med J. 2013 Nov 11;16;91.

DOI: 10.11604/pamj.2013.16.91.3307 [Crossref]

16. Proulx F, Martinot A, Leclerc F, Lacroixi J, Gauvinl F, Chaibou $M$ et al. Transfusions of globular concentrate in pediatric resuscitation. Réa Urg. 2000;9(5)339-344.

DOI: $10.1016 / \mathrm{S} 1164-6756(00) 90073-2$ [Crossref]

17. Rakotosalama N. Transfusion practices in the emergency and intensive care unit, $\mathrm{CHU}$ Mahajanga Androva [Thesis]. Human medicineMahajanga. 2005 Dec;55p.

Available at: [Article] [Crossref]

18. Rahanitrarisoa M. Evaluation of transfusion practice in the surgical resuscitation department, CHU Ampefiloha [Thesis]. Human medicine- Antananarivo. 2004 May;n 6959;54p.

Available online at: [Article] [Crossref]

19. Libite P, Tchamda C, Mosoko J, Nouetagne S, Makang J, Barrère B et al. Demographic Survey and Health. Cameroon. 2005 June;3;165-75.

Available at: [Article] [Crossref]

20. Garba M. Transfusion requirements in the haematology/medical oncology and internal medicine department of the $\mathrm{CHU}$ du Point "G" from January 1998 to December 2003 [Theses]. Faculty of Medicine- Bamako. 2004;56p.

Available at: [Article] [Crossref]

21. Ouethy N. Analysis of transfusion activities in the Pediatrics Department of the Gabriel Touré hospital and university center [thesis]. Human medicine- Bamako. 2000;29;61p.

[Crossref]

22. Chobli M. Blood transfusion in Africa- Which blood for which patients in Africa?- Cotonou Faculty of Medicine - Benin Republic. RAMUR. 2011;16(1)1-2.

Available online at: [Article] [Crossref] 